\title{
MAP2K2 wt Allele
}

National Cancer Institute

\section{Source}

National Cancer Institute. MAP2K2 wt Allele. NCI Thesaurus. Code C106607.

Human MAP2K2 wild-type allele is located in the vicinity of 19p13.3 and is approximately $34 \mathrm{~kb}$ in length. This allele, which encodes dual specificity mitogen-activated protein kinase kinase 2 protein, is involved in both MAPK and toll-like receptor signaling pathways. Mutation of the gene is associated with cardiofaciocutaneous syndrome. 